\title{
Preface
}

\section{"Sources and rapid biogeochemical transformation of dissolved organic matter in the Atlantic surface ocean"}

\author{
B. P. Koch ${ }^{1,2}$ and G. Kattner ${ }^{1}$ \\ ${ }^{1}$ Alfred Wegener Institute for Polar and Marine Research, Ecological Chemistry, Am Handelshafen 12, \\ 27570 Bremerhaven, Germany \\ ${ }^{2}$ University of Applied Sciences, An der Karlstadt 8, 27568 Bremerhaven, Germany \\ Correspondence to: B. P. Koch (boris.koch@awi.de)
}

\section{Introduction}

One of the most important issues needed to be studied to better understand global fluxes of marine organic matter is to resolve its molecular characteristics and mechanisms which convert fresh, labile biomolecules into semi-labile and refractory dissolved organic compounds (Jiao et al., 2010) which resist degradation for an average time of 5000 years (Bauer et al., 1992; Williams and Druffel, 1987). From a chemical point of view, the persistence of marine dissolved organic matter (DOM) is very unusual. The mostly oxygenand nutrient-rich oceanic water column should be conducive to a rapid microbial degradation of organic matter and subsequent release of $\mathrm{CO}_{2}$. Contrary to this expectation, however, a significant portion of the atmospheric carbon remains in the DOM of the oceans and circulates in global currents on long time scales. Despite the importance of gaining better insights into the molecular mechanisms affecting organic carbon dynamics, very little is known about these processes. Thus, recent reports from the intergovernmental panel on climate change (Denman et al., 2007) barely considered potential changes in quality, quantity and fluxes of marine organic matter.

In the oceans, dissolved organic substances constitute an important source of organic carbon and organic nitrogen (Hansell et al., 2009). The pool of dissolved organic carbon (DOC) exceeds the amount of carbon stored in marine animals, plants and bacteria by a factor of about 200 . The majority of DOM in the oceans is originally formed from $\mathrm{CO}_{2}$ by plankton and land plants during photosynthesis. The DOM, resulting from this organic material, is directly released into the water by marine plankton and during the degradation of these organisms. Also, DOM can be transported into the oceans via rivers and atmospheric deposits via aerosols. A small fraction of marine DOM, such as persistent organic pollutants or black carbon derivatives, can be derived from anthropogenic activities. DOM can bind to trace metals such as iron and is therefore also responsible for their distribution in the sea.

The complex composition of DOM is an enormous analytical challenge, resulting in sparse information on chemical structures. The DOM complexity prevents resolution of single molecules by chromatographic separation or conventional mass spectrometry. However, within the last 10 years analytical instruments, which can deliver molecular signals, improved tremendously. Namely, improvements of nuclear magnetic resonance spectroscopy (NMR) and Fourier transform ion cyclotron resonance mass spectrometry (FT-ICR MS) opened a new analytical window for the molecular characterization of natural organic matter (e.g. Stenson et al., 2003; Kujawinski et al., 2004; Koch et al., 2005; Hertkorn et al., 2008; Witt et al., 2009).

Meridional transits of polar research vessels offer a great opportunity to perform long-distance surface water transects with continuous water and air sampling, since frequent stops for long station work are usually not possible during such transit cruises. Trace metal (Pohl et al., 2011; Helmers, 1996) and plankton studies (Robinson et al., 2009) and a recent GEOTRACES pilot study in the Atlantic Ocean (Rutgers van der Loeff, 2007) are great examples for the importance of such projects. Previous work along the north-south transect also provided a high resolution comparison of bacterial and primary production (Hoppe et al., 2002). The authors suggested that the observed net heterotrophy required 
bioavailable organic matter subsidies from (i) equatorial upwelling of pre-aged DOC, (ii) transport of DOC via currents from spatially remote upwelling systems and rivers, and (iii) temporal transfer as a semi-labile degradation product of primary production.

The major aim of the interdisciplinary ANT-XXV/1 cruise of R/V Polarstern from Bremerhaven to Cape Town (31 October to 3 December 2008) was to obtain detailed molecular characteristics of DOM in the Atlantic surface ocean and to relate the data to different climatic, hydrographical, and biological regimes. Our goal was to acquire a multi-disciplinary data set for the characterization of DOM sources and transformation processes from the North to the South Atlantic Ocean. For this study we hypothesized:

"The majority of the molecular changes in DOM are taking place in the uppermost water column. This conversion occurs almost instantaneously after release by primary production or atmospheric input and is mediated by microbial and photochemical processes. After this quick process, the reworked material is more similar to the refractory deep-sea DOM than to the fresh initial DOM.

\section{Overview of oceanographic and physico-chemical parameters}

Here we present, as an introduction, the hydrographic conditions and nutrient concentrations as a basis for the DOM studies during the cruise (Fig. 1). The cruise track crossed, from north to south, following oceanic ecological provinces previously defined by (Longhurst 2006): the Northeast Atlantic Shelves Province (NECS), the North Atlantic Drift Province (NADR), the North Atlantic Subtropical Gyral Province (East, NASE), the North Atlantic Tropical Gyral Province (NATR), probably touching the Canary Current Coastal Province (CNRY), the Eastern Tropical Atlantic Province (ETRA), the South Atlantic Gyral Province (SATL), and finally the Benguela Current Coastal Province (BENG). Dry deposition of dust originating from the African continent plays an important role for the organic and inorganic composition of the Atlantic surface waters especially in the regions of dust transport from the Sahara.

Beside the continuous water and air sampling during the entire cruise, "shallow" stations down to $200 \mathrm{~m}$ including the deep chlorophyll maximum layer were performed every day. In addition, at 8 "deep" stations, samples from the entire water column were taken. With the deep CTD casts, the main water masses sampled were Eurafrican Mediterranean Water (EMW; $\sim 1000 \mathrm{~m}$ water depth, Fig. 2 ) at $35^{\circ} \mathrm{N}$, Antarctic Intermediate Water (AAIW; $\sim 1000 \mathrm{~m}$ water depth) and North Atlantic Deep Water ( $2000 \mathrm{~m}$ water depth) which was increasingly mixed with Antarctic Bottom Water (AABW) towards the south (Tomczak and Godfrey, 2003).

The coastal regions of Europe and South Africa were characterized by higher nutrient concentrations

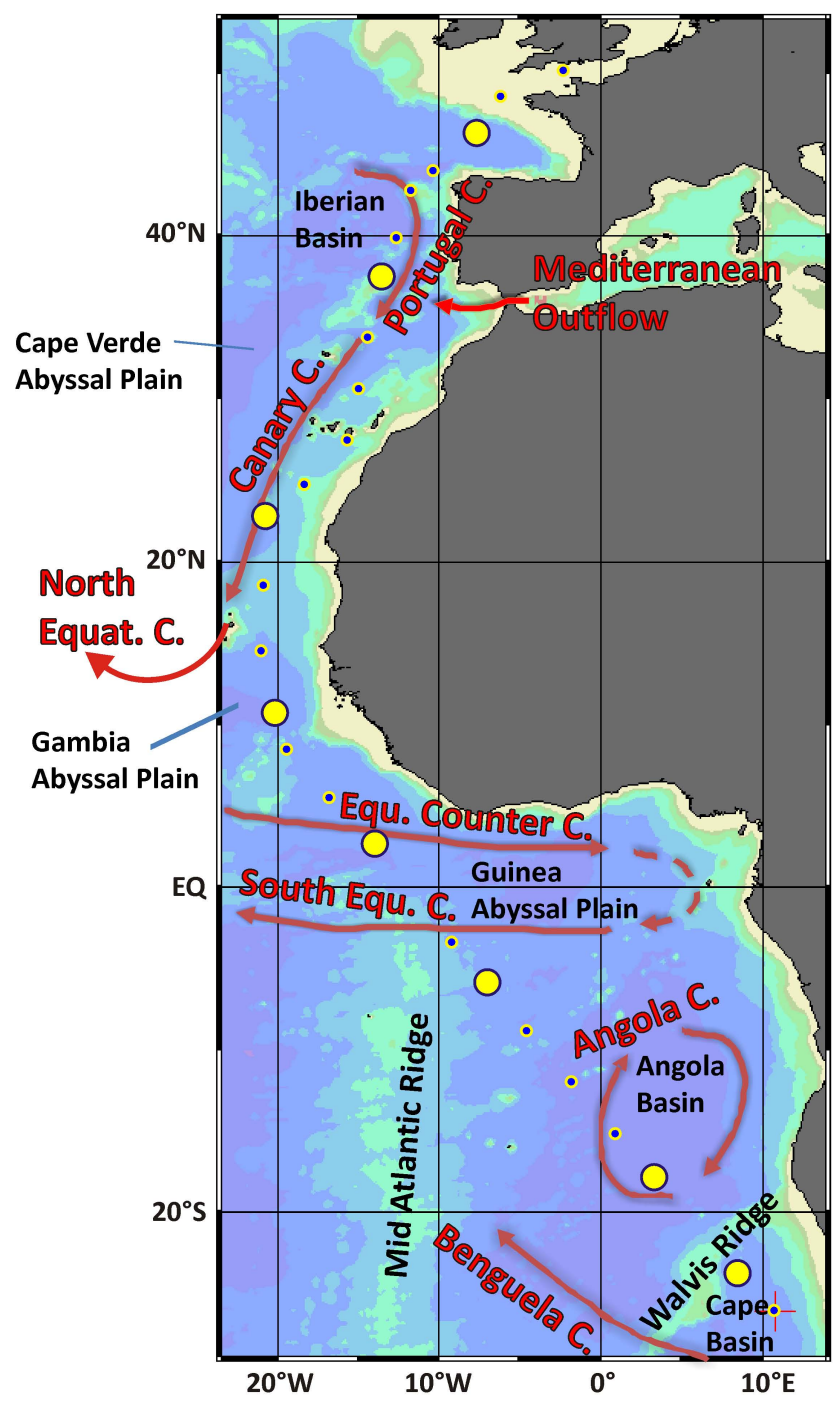

Fig. 1. Cruise track and stations of the R/V Polarstern expedition ANT-XXV/1 including major surface currents. Continuous surface measurements were performed along the transect. Shallow stations (blue dots) covered the upper $200 \mathrm{~m}$, and deep stations covered the entire water column (yellow dots). Figure by courtesy of Gerd Rohardt (AWI).

(mesotrophic) whereas the remaining transect proceeded through oligotrophic waters in the subtropical and tropical regions (Fig. 3). The North Atlantic Gyre showed high salinities (36.9) owing to strong evaporation followed by lower salinities (34.3) north of the Equator in the intertropical convergence zone (ITCZ) caused by heavy rainfall and freshwater discharge from the tropical rivers. Here, the water temperatures reached maximum values of $29^{\circ} \mathrm{C}$ (Fig. 3). South of the Equator salinities increased again but without signals of upwelling that occurs strongest during summer. The highest DOC concentrations were measured north of the Equator in the region of the highest surface temperatures, and the lowest salinities overlapped with the southern border of the 

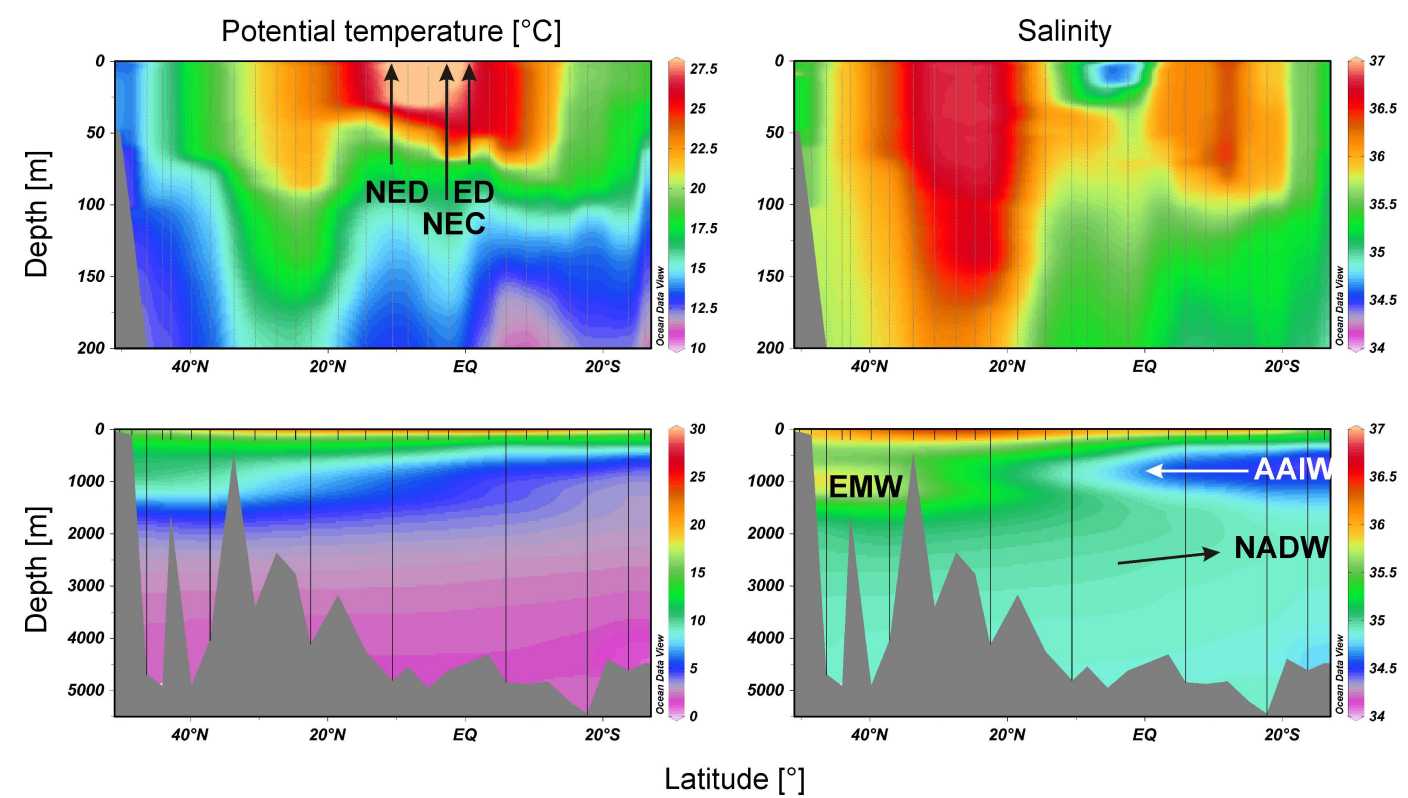

Fig. 2. Potential temperature (temperature at standard reference pressure) and salinity for two different depth intervals: euphotic zone (upper $200 \mathrm{~m}$; upper two graphs) and total water column (lower two graphs). Main deep water masses were Eurafrican Mediterranean Water (EMW), Antarctic Intermediate Water (AAIW) and North Atlantic Deep Water (NADW). Within the inner-tropical convergence zone, the North Equatorial Divergence (NED), North Equatorial Convergence (NEC) and Equatorial Divergence (ED) are marked.

North Atlantic Gyre (Fig. 3). Below the mixed layer (photic zone) DOC concentrations were $54 \mu \mathrm{M}$, close to the deep Atlantic water values $(\sim 47 \mu \mathrm{M})$. The interplay between production and consumption as well as the influence by photooxidation and the depth of the mixed layer determined the decreasing gradient of DOC from the surface to the deep ocean.

DOC was also negatively correlated with inorganic nutrients (nitrate), and radiocarbon (Flerus et al., 2012) and positively correlated with bacterial abundance (DAPI counts and colony forming units; Neogi et al., 2011) and activity (leucine activity; Fig. 3; Flerus et al., 2012) which were in turn correlated with temperature. These results are consistent with earlier findings which pointed to the close interaction of temperature, DOC, and microbial activity and abundance (Pomeroy and Wiebe, 2001; Lonborg et al., 2010; Kirchman et al., 2005). Our results suggest that the microbial community is a major player determining the DOC concentration, leaving a molecular fingerprint in DOM.

\section{Molecular biogeochemistry of dissolved organic matter}

The articles of this special issue highlight the relationship between molecular characteristics of DOM and the environmental conditions in water masses of different climatic zones in the eastern Atlantic Ocean. The molecular characterization of DOM was performed in particular using ultra high resolution FT-ICR MS and NMR spectrometry (Flerus et al., 2012; Hertkorn et al., 2012; Schmitt-Kopplin et al.,
2012). The molecular biogeochemical patterns were closely related to plankton (Taylor et al., 2011) and microbial ecology (Friedline et al., 2012; Neogi et al., 2011), ageing of the organic material (Flerus et al., 2012), physical oceanography and nutrient availability. The molecular biogeochemical signals were even tracked into the atmosphere: A fraction of the DOM molecules from the water column was transferred from the water surface into the atmosphere via sea spray (SchmittKopplin et al., 2012). The determination of optical water properties (Röttgers and Koch, 2012) and pigment analyses (Taylor et al., 2012) provided important details on the phytoplankton composition in the various water masses, and served for the characterization of ecological provinces along the transect. Further emphasis was laid on individual organic trace compounds derived from anthropogenic sources (Xie et al., 2011).

Bacterial abundance (specifically of Vibrio) was most closely connected to the availability of dissolved rather than particulate matter (Neogi et al., 2011). The degree of (microbial) turnover of DOM was mirrored in the radiocarbon age and was linked to chemical changes at the molecular level (Flerus et al., 2012). The structural DOM characterization by NMR generally suggested that there is a substantial contribution of olefins apart from the aromatic fraction (Hertkorn et al., 2012). These structures are expected to be more closely related to the biochemical origin and in turn predominantly define the molecular processes which occur rapidly at the sea surface. Based on conventional spectroscopic methods, a ubiquitous degradation product was 

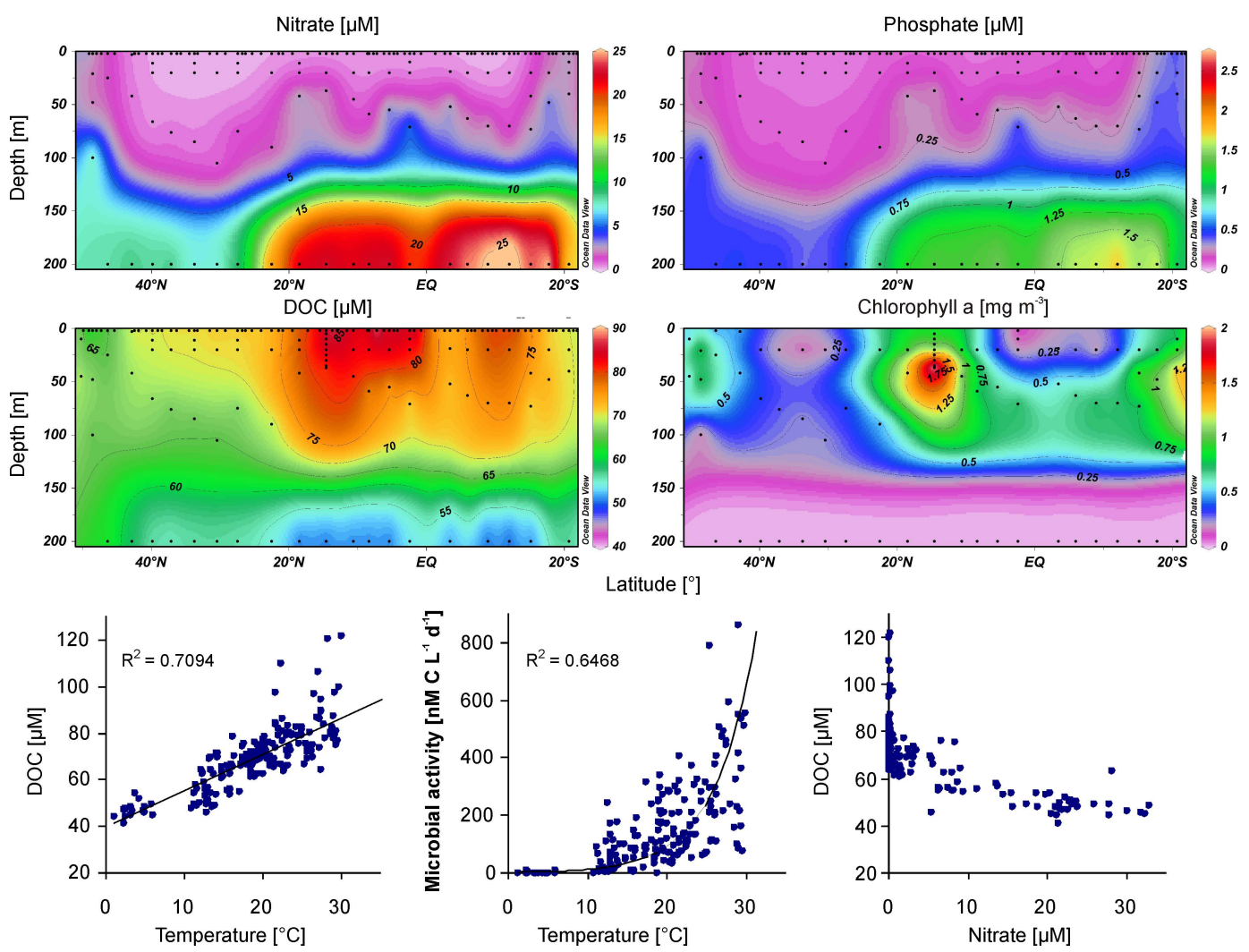

Fig. 3. Nitrate, phosphate, DOC and chlorophyll $a$ concentrations in the upper $200 \mathrm{~m}$ along the transect. For the total data set (all depths including deep stations) DOC was correlated with temperature and nitrate (below surface at DOC concentrations $<60 \mu \mathrm{M}$ ). Microbial activity (leucine) was also correlated with DOC and temperature $(p<0.001)$.

\section{Atlantic Surface Ocean (0-20 m)}

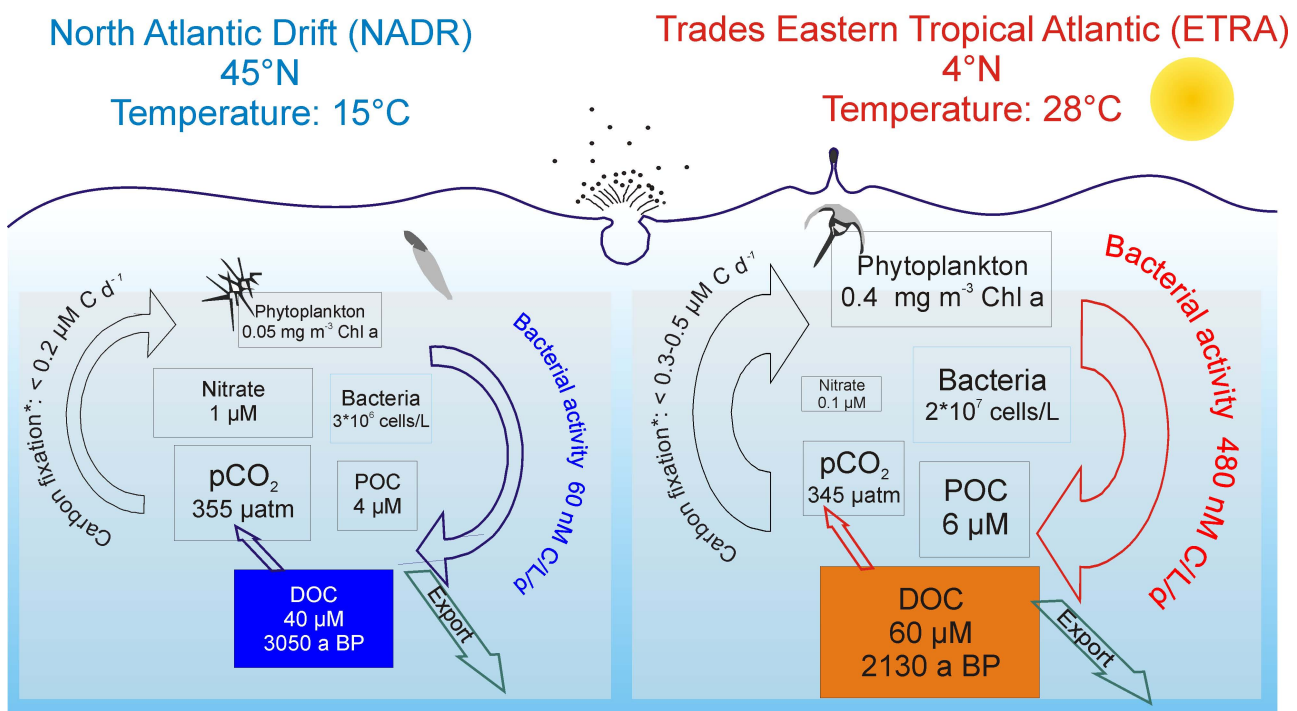

Fig. 4. Schematic overview of important variables which were measured during the ANT-XXV/1 cruise and which were related to the DOC distribution and molecular characteristics of DOM in the surface ocean. Values are given as averages for the upper $20 \mathrm{~m}$ of the water column at $45^{\circ} \mathrm{N}$ and $4^{\circ} \mathrm{N}$. *Data taken from Poulton et al., 2006. 
identified during the cruise and at other places worldwide, and it is suggested to originate from algal pigments (Röttgers and Koch, 2012). The increase of N-heterocycles, as detected by NMR (Hertkorn et al., 2012), might explain the absorption characteristics of this unidentified degradation product in the subsurface.

Figure 4 summarizes important compartments and control variables for the cycling of DOM and its molecular composition during our cruise: Under oligotrophic conditions in the warm tropical ocean near the Equator, DOC concentrations were higher than in the mesotrophic mid latitudes of the Northern Atlantic Ocean. The surplus of DOC in the tropical ocean was derived from higher production and carbon fixation (Poulton et al., 2006) and accordingly higher particulate organic carbon (POC) concentration. However, neither production nor POC were correlated with DOC. Instead, DOC correlated most significantly with bacterial abundance and bacterial activity. Since inorganic nutrients are scarce near the Equator, the cycling of nutrients must be fast to sustain primary production. Compared to the mid latitudes, where microbial activity is lower, additional DOC "leaks" out of this organic matter cycle. This surplus of DOC in the tropical oceans results from an inefficient processing of organic matter by bacterioplankton (Obernosterer and Herndl, 1995; Ogawa et al., 2001) as bacterial utilization of DOC is often limited by the availability of nitrogen or phosphorus (Zweifel et al., 1993). In addition, abiotic transformation by e.g. photodegradation of originally labile DOM can lead to the formation of semi-labile and eventually recalcitrant compounds (Tranvik and Kokalj, 1998; Ogawa et al., 2001). The multitude of all of these parameters is of particular relevance for the cycling of organic matter and nutrients in open ocean oligotrophic systems, where internal cycling in the pelagic zone is a main mechanism for maintaining primary production.

Acknowledgements. We thank the captain and crew of the R/V Polarstern for their professional help and support. We appreciate the excellent cooperation of all scientists, technicians and students on board and during the preparation of the manuscripts. This special issue is dedicated to the memory of Christa Pohl († 25 March 2012).

\section{References}

Bauer, J. E., Williams, P. M., and Druffel, E. R. M.: ${ }^{14}$ C activity of dissolved organic carbon fractions in the north-central Pacific and Sargasso Sea, Nature, 357, 667-670, 1992.

Denman, K. L., Brasseur, G., Chidthaisong, A., Ciais, P., Cox, P. M., Dickinson, R. E., Hauglustaine, D., Heinze, C., Holland, E., Jacob, D., Lohmann, U., Ramachandran, S., da Silva Dias, P. L., Wofsy, S. C., and Zhang, X.: Couplings Between Changes in the Climate System and Biogeochemistry., in: Climate Change 2007: The Physical Science Basis. Contribution of Working Group I to the Fourth Assessment Report of the Intergovernmental Panel on Climate Change, edited by: Solomon, S., Qin, D., Manning, M., Chen, Z., Marquis, M., Averyt, K. B., Tignor, M., and Miller, H. L., Cambridge University Press, Cambridge, United Kingdom and New York, NY, USA, 2007.

Flerus, R., Lechtenfeld, O. J., Koch, B. P., McCallister, S. L., Schmitt-Kopplin, P., Benner, R., Kaiser, K., and Kattner, G.: A molecular perspective on the ageing of marine dissolved organic matter, Biogeosciences, 9, 1935-1955, doi:10.5194/bg-9-19352012, 2012.

Friedline, C. J., Franklin, R. B., McCallister, S. L., and Rivera, M. C.: Bacterial assemblages of the eastern Atlantic Ocean reveal both vertical and latitudinal biogeographic signatures, Biogeosciences, 9, 2177-2193, doi:10.5194/bg-9-2177-2012, 2012.

Hansell, D. A., Carlson, C. A., Repeta, D. J., and Schlitzer, R.: Dissolved organic matter in the ocean: a controversy stimulates new insights, Oceanography, 22, 202-211, 2009.

Helmers, E.: Trace metals in suspended organic matter of Atlantic Ocean surface water $\left(40^{\circ} \mathrm{N}\right.$ to $\left.20^{\circ} \mathrm{S}\right)$, Mar. Chem., 53, 51-67, 1996.

Hertkorn, N., Frommberger, M., Witt, M., Koch, B. P., SchmittKopplin, P., and Perdue, E. M.: Natural organic matter and the event horizon of mass spectrometry, Anal. Chem., 80, 89088919, doi:10.1021/ac800464g, 2008.

Hertkorn, N., Harir, M., Koch, B. P., Michalke, B., Grill, P., and Schmitt-Kopplin, P.: High field NMR spectroscopy and FTICR mass spectrometry: powerful discovery tools for the molecular level characterization of marine dissolved organic matter from the South Atlantic Ocean, Biogeosciences Discuss., 9, 745-833, doi:10.5194/bgd-9-745-2012, 2012.

Hoppe, H. G., Gocke, K., Koppe, R., and Begler, C.: Bacterial growth and primary production along a north-south transect of the Atlantic Ocean, Nature, 416, 168-171, 2002.

Jiao, N., Herndl, G. J., Hansell, D. A., Benner, R., Kattner, G., Wilhelm, S. W., Kirchman, D. L., Weinbauer, M. G., Luo, T. W., Chen, F., and Azam, F.: Microbial production of recalcitrant dissolved organic matter: long-term carbon storage in the global ocean, Nat. Rev. Microbiol., 8, 593-599, doi:10.1038/nrmicro2386, 2010.

Kirchman, D. L., Malmstrom, R. R., and Cottrell, M. T.: Control of bacterial growth by temperature and organic matter in the Western Arctic, Deep-Sea Res. Pt II, 52, 3386-3395, doi:10.1016/j.dsr2.2005.09.005, 2005.

Koch, B. P., Witt, M., Engbrodt, R., Dittmar, T., and Kattner, G.: Molecular formulae of marine and terrigenous dissolved organic matter detected by electrospray ionisation Fourier transform ion cyclotron resonance mass spectrometry, Geochim. Cosmochim. Ac., 69, 3299-3308, 2005.

Kujawinski, E. B., Del Vecchio, R., Blough, N. V., Klein, G. C., and Marshall, A. G.: Probing molecular-level transformations of dissolved organic matter: insights on photochemical degradation and protozoan modification of DOM from electrospray ionization Fourier transform ion cyclotron resonance mass spectrometry, Mar. Chem., 92, 23-37, 2004.

Lonborg, C., Alvarez-Salgado, X. A., Martinez-Garcia, S., Miller, A. E. J., and Teira, E.: Stoichiometry of dissolved organic matter and the kinetics of its microbial degradation in a coastal upwelling system, Aquat. Microb. Ecol., 58, 117-126, doi:10.3354/ame01364, 2010. 
Longhurst, A. R.: Ecological geography of the sea, 2 Edn., Academic Press, San Diego, 560 pp., 2006.

Neogi, S. B., Koch, B. P., Schmitt-Kopplin, P., Pohl, C., Kattner, G., Yamasaki, S., and Lara, R. J.: Biogeochemical controls on the bacterial populations in the eastern Atlantic Ocean, Biogeosciences, 8, 3747-3759, doi:10.5194/bg-8-3747-2011, 2011.

Obernosterer, I. and Herndl, G. J.: Phytoplankton extracellular release and bacterial growth: dependence on the inorganic N:P ratio, Mar. Ecol. Prog. Ser., 116, 247-257, 1995.

Ogawa, H., Amagai, Y., Koike, I., Kaiser, K., and Benner, R.: Production of refractory dissolved organic matter by bacteria, Science, 292, 917-920, 2001.

Pohl, C., Croot, P. L., Hennings, U., Daberkow, T., Budeus, G., and von der Loeff, M. R.: Synoptic transects on the distribution of trace elements $(\mathrm{Hg}, \mathrm{Pb}, \mathrm{Cd}, \mathrm{Cu}, \mathrm{Ni}, \mathrm{Zn}, \mathrm{Co}, \mathrm{Mn}, \mathrm{Fe}$, and $\mathrm{Al})$ in surface waters of the Northern- and Southern East Atlantic, J. Mar. Syst., 84, 28—41, doi:10.1016/j.jmarsys.2010.08.003, 2011.

Pomeroy, L. R. and Wiebe, W. J.: Temperature and substrates as interactive limiting factors for marine heterotrophic bacteria, Aquati. Microb. Ecol., 23, 187-204, 2001.

Poulton, A. J., Holligan, P. M., Hickman, A., Kim, Y. N., Adey, T. R., Stinchcombe, M. C., Holeton, C., Root, S., and Woodward, E. M. S.: Phytoplankton carbon fixation, chlorophyll-biomass and diagnostic pigments in the Atlantic Ocean, Deep-Sea Res. Pt. II, 53, 1593-1610, doi:10.1016/j.dsr2.2006.05.007, 2006.

Robinson, C., Holligan, P., Jickells, T., and Lavender, S.: The Atlantic Meridional Transect Programme (19952012) Foreword, Deep-Sea Res. Pt. II, 56, 895-898, doi:10.1016/j.dsr2.2008.10.005, 2009.

Röttgers, R. and Koch, B. P.: Spectroscopic detection of a ubiquitous dissolved pigment degradation product in subsurface waters of the global ocean, Biogeosciences, 9, 2585-2595, doi:10.5194/bg-9-2585-2012, 2012.

Rutgers van der Loeff, M.: The expedition ANT-XXIII/1 of the research vessel Polarstern in 2005, Ber. Polarforsch. Meeresforsch., 556, 140 pp., 2007.
Schmitt-Kopplin, P., Liger-Belair, G., Koch, B. P., Flerus, R., Kattner, G., Harir, M., Kanawati, B., Lucio, M., Tziotis, D., Hertkorn, N., and Gebefügi, I.: Dissolved organic matter in sea spray: a transfer study from marine surface water to aerosols, Biogeosciences, 9, 1571-1582, doi:10.5194/bg-9-1571-2012, 2012.

Stenson, A. C., Marshall, A. G., and Cooper, W. T.: Exact masses and chemical formulas of individual Suwannee River fulvic acids from ultrahigh resolution electrospray ionization Fourier transform ion cyclotron resonance mass spectra, Anal. Chem., 75, 1275-1284, 2003.

Taylor, B. B., Torrecilla, E., Bernhardt, A., Taylor, M. H., Peeken, I., Röttgers, R., Piera, J., and Bracher, A.: Bio-optical provinces in the eastern Atlantic Ocean and their biogeographical relevance, Biogeosciences, 8, 3609-3629, doi:10.5194/bg-8-36092011, 2011.

Tomczak, M. and Godfrey, J. S.: Regional oceanography: an introduction, 2 Edn., Daya Publishing House, Delhi, 390 pp., 2003.

Tranvik, L. and Kokalj, S.: Decreased biodegradability of algal DOC due to interactive effects of UV radiation and humic matter, Aquat. Microb. Ecol., 14, 301-307, 1998.

Williams, P. M. and Druffel, E. R. M.: Radiocarbon in dissolved organic matter in the central North Pacific Ocean, Nature, 330, 246-248, 1987.

Witt, M., Fuchser, J., and Koch, B. P.: Fragmentation studies of Fulvic Acids using collision induced dissociation Fourier transform ion cyclotron resonance mass spectrometry, Anal. Chem., 81, 2688-2694, 2009.

Xie, Z., Koch, B. P., Möller, A., Sturm, R., and Ebinghaus, R.: Transport and fate of hexachlorocyclohexanes in the oceanic air and surface seawater, Biogeosciences, 8, 2621-2633, doi:10.5194/bg-8-2621-2011, 2011.

Zweifel, U. L., Norman, B., and Hagstrom, A.: Consumption of dissolved organic carbon by marine bacteria and demand for inorganic nutrients, Mar. Ecol. Prog. Ser., 101, 23-32, 1993. 